\title{
Kajian Coreflooding Test di Laboratorium Menggunakan Injeksi Surfactant-Polymer untuk Meningkatkan Produksi Lapangan Minyak
}

\section{Laboratory Core-flooding Test of Surfactant-Polymer Injection Method for Oilfield Production Improvement}

\author{
Dedy Kristanto $^{1)^{*}}$, Wibowo ${ }^{2)}$, Hariyadi ${ }^{3)}$ dan Y. Deddy Hermawan ${ }^{4)}$ \\ ${ }^{1,2,3)}$ Jurusan Teknik Perminyakan, Fakultas Teknologi Mineral, UPN "Veteran” Yogyakarta \\ 4) Jurusan Teknik Kimia, Fakultas Teknologi Industri, UPN “Veteran” Yogyakarta \\ Jl. Pajajaran 104 (Lingkar Utara), Condongcatur Yogyakarta 55283
}

\author{
Artikel histori : \\ Diterima 1 April 2019 \\ Diterima dalam revisi 15 Mei 2019 \\ Diterima 20 Juni 2019 \\ Online 30 Juni 2019
}

\begin{abstract}
ABSTRAK: Penggunaan injeksi kimia telah banyak digunakan pada lapangan minyak dalam skala yang besar. Beberapa kasus mengalami keberhasilan yang tinggi dan di sisi lain banyak juga yang mengalami kegagalan pada saat pelaksanaan full-scale project. Sebelum dilakukannya injeksi kimia, salah satu hal yang sebaiknya dilakukan adalah mencoba dan merealisasikan chemical yang layak digunakan berdasarkan karakteristik reservoirnya yang menjadi target untuk peningkatan perolehan minyak. Coreflooding menjadi salah satu hal yang penting dalam penilaian kinerja chemical yang digunakan setelah tahapan screening. Kajian coreflooding di laboratorium menunjukkan bahwa hasil pengukuran sifat surfaktan dan polimer memberikan hasil yang baik untuk digunakan sebagai bahan injeksi dalam meningkatkan perolehan minyak. Injeksi surfactant-polymer dengan konsentrasi 3000 ppm dan 1000 ppm dengan mekanisme injeksi sebanyak 0,3 PV surfaktan dan 0,2 PV polimer menghasilkan peningkatan perolehan minyak sebesar $12,89 \%$. Selanjutnya berdasarkan hasil analisa secara kualitatif didapatkan bahwa penggunaan surfaktan SS-B8020 sebagai fluida injeksi tidak menyebabkan terjadinya penyumbatan pada pori-pori batuan reservoir, yang berarti bahwa fluida injeksi kompatibel dengan batuan reservoir tersebut.
\end{abstract}

Kata Kunci: Coreflooding, enhanced oil recovery, injeksi kimia, surfactant-polymer

\begin{abstract}
The utilization of chemical flooding to improve oil production in a large scale has many used for the oil field. Some cases have a success, and the others have fail when full scale project implemented. Before chemical flooding conducted, once of the recommended best practice to be done is chemical compatibility based on the reservoir characteristic of the layer as a target in improving oil recovery. Hence, coreflooding test in the laboratory to be an important thing to conduct in other to knows and determine the chemical performance after screening phase. The study of coreflooding test in the laboratory, shows that the measurement of surfactant and polymer properties have a good results to be used as an injection fluid in other to improve oil production. Surfactant - polymer injection which has concentrations of $3000 \mathrm{ppm}$ and $1000 \mathrm{ppm}$ with injection mechanism of $0.3 \mathrm{PV}$ surfactant and $0.2 \mathrm{PV}$ polymer gives the result of improving oil production it about $12.89 \%$. Furthermore, based on the qualitative analysis obtained that the used of surfactant SS-B8020 as an injection fluid shown that plugging has not occurred in the reservoir rock pores, it means that the injection fluid was compatible with these reservoir rock.
\end{abstract}

Keywords: Coreflooding, enhanced oil recovery, chemical flooding, surfactant-polymer

\section{Pendahuluan}

Seiring dengan bertambahnya masa produksi suatu lapangan, produktivitasnya semakin berkurang. Hal ini disebabkan bertambahnya jumlah minyak yang telah diproduksikan dari reservoir, yang sangat berpengaruh terhadap berkurangnya energi alamiah reservoir (tekanan

\footnotetext{
* Corresponding Author: +62-8156704084; fax : +62-274-487815

Email: dedykris.upn@gmail.com
}

reservoir) yang diperlukan untuk mengalirkan minyak ke dalam sumur produksi. Untuk dapat memproduksikan minyak setelah energi alamiah reservoir berkurang maka diperlukan tahap pengurasan minyak selanjutnya.

Injeksi kimia adalah salah satu metode pengurasan minyak tahap lanjut dengan jalan menambahkan zat-zat kimia ke dalam reservoir melalui sumur injeksi. Penambahan zat-zat kimia ini bertujuan untuk merubah sifat fisik dari fluida reservoirnya, dengan sasaran utama adalah untuk menurunkan tegangan antar muka, 
dikarenakan jika tegangan antar muka memiliki nilai yang besar maka mobilitas minyak di reservoir akan berkurang sehingga perolehan minyak pada tahapan primary recovery maupun secondary recovery akan berdampak pada laju produksi yang menurun. Beberapa penelitian tentang injeksi kimia telah dilakukan dengan baik oleh peneliti sebelumnya baik itu secara kajian studi kelayakan (Wang, Z. et. al,, 2001; Ayirala, C.S., 2002; Berger, D, et. al., 2002; Goddard, et. al., 2004; Anderson, A. G., 2006; Kristanto, D, et. al. 2008; Nugroho, S. B., et. al., 2012) dan eksperimen di laboratorium (Buckley, S. J., 1997; Ashayer, R, et, al., 2000; Kristanto, D, et. al., 2006 dan Kristanto, D., 2012).

Pada umumnya injeksi kimia di klasifikasikan menjadi tiga jenis, yaitu injeksi alkaline, injeksi polimer, dan injeksi surfaktan. Seiring dengan perkembangan penelitian ditemukan kombinasi antara injeksi polimer dengan injeksi surfaktan yang lebih dikenal dengan micellar-polymer flooding. Dalam hal ini, micellar-polymer flooding memiliki tingkat perolehan yang lebih tinggi dibanding dengan ketiga jenis injeksi kimia yang lainnya. Injeksi kimia ini memiliki prospek yang baik pada reservoirreservoir yang telah sukses dilakukan injeksi air atau waterflooding (Abrams, A., 1988). Selain itu, injeksi kimia ini memiliki nilai ekonomis yang tinggi (Goddard, et. al. 2004). Di samping itu, ada beberapa faktor yang dapat mempengaruhi keberhasilan dari injeksi kimia ini seperti temperatur, jenis reservoir, permeabilitas dan wettabilitas (Abrams, A., 1988; Ashayer, R., et. al., 2000; Ayirala, C. S., 2002; Anderson, A. G., 2006).

Tujuan dari kajian ini adalah melakukan coreflooding test menggunakan surfaktan dan polimer terpilih, menentukan skenario injeksi untuk memperoleh kenaikan perolehan minyak yang optimal, serta uji kompatibilitas surfaktan dan polimer sebelum diaplikasikan di lapangan.

\section{Metode Penelitian}

Surfaktan dapat menurunkan tegangan permukaan dan dapat meningkatkan perolehan minyak sebagaimana telah banyak dibuktikan oleh para peneliti sebelumnya. Salah satunya adalah Berger, D., et. al., 2002, yang menyatakan bahwa surfaktan menurunkan tegangan permukaan antara air formasi (brine) dan minyak tersisa (residual oil) dan pengaruhnya yaitu akan meningkatkan capillary number. Capillary number $\left(N_{c}\right)$ digunakan untuk menyatakan pelepasan pada minyak yang masih tertahan didalam media berpori. Capillary number $\left(N_{c}\right)$ adalah fungsi dari Darcy velocity $(v)$ yang mendesak pergerakan pada fluida yang terperangkap dalam pori batuan, dan viskositas $(\mu)$ sebagai tahanan (resistance) fluida untuk mengalir. Pengaruh capillary number terhadap perolehan minyak dapat dilihat pada Gambar 1.

Capillary number yang bernilai sekitar $10^{-6}$ ditemukan pada kasus-kasus lapangan yang telah dilakukan waterflooding (pendesakan dengan menggunakan air) dan ini akan meningkat dua sampai tiga kalinya untuk mendesak minyak sampai batas maksimum (Abrams, A.,
1988; Berger, D., et. al., 2002). IFT (interfacial tension) pada kasus waterflooding berkisar $10^{1}$ sampai $10^{0} \mathrm{mN} / \mathrm{m}$ (Abrams, A., 1988). Penggunaan surfaktan sendiri dapat menurunkan tegangan permukaan sampai $10^{-2} \mathrm{mN} / \mathrm{m}$ atau kurang, dimana hal tersebut akan meningkatkan capillary number dua sampai tiga kalinya (Abrams, A., 1988; Ashayer, R., et. al., 2000; Berger, D., et. al., 2002).

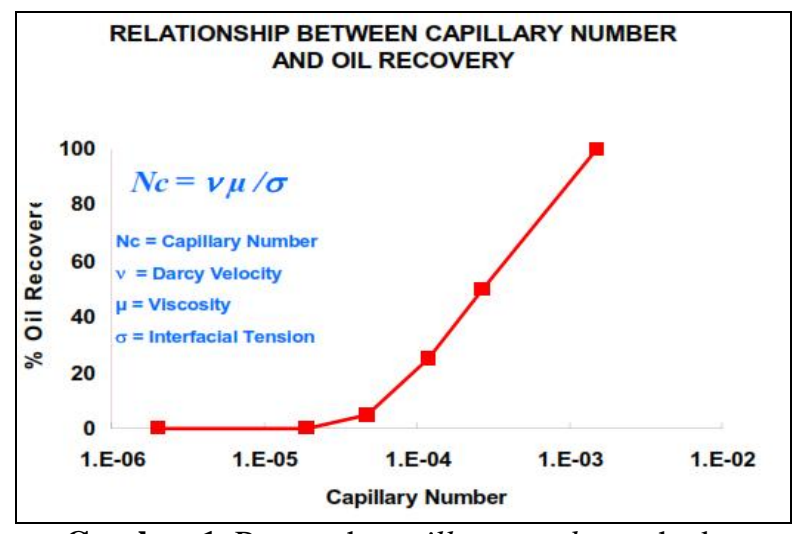

Gambar 1. Pengaruh capillary number terhadap perolehan minyak (After Berger, D., et. al., 2002)

\subsection{Material yang Digunakan}

Dalam percobaan coreflooding injeksi kimia digunakan material surfaktan dan polimer (OilChem-USA); serta sampel air formasi, minyak dan batuan reservoir yang diambil dari Lapangan Limau. Rincian dari bahan-bahan tersebut adalah :

- Surfaktan tipe SS-B8020, larut dalam air dengan pH antara 5-8, kandungan aktif 50\%.

- Polimer yang digunakan HYBOMAX 4785.

- Sampel minyak diambil dari Tank-02 SP-VII

- Air yang digunakan merupakan air formasi dari sumur L5A-217 Blok Q-22

- Batuan reservoir diambil dari core sumur L5A-217 pada kedalaman antara 1562.88 - $1563.70 \mathrm{~m}$ yang merupakan batupasir.

Jenis surfaktan yang digunakan adalah surfaktan dengan seri super-surfactant (SS). Pemilihan jenis surfaktan ini didasarkan pada beberapa keuntungan, yaitu :

\section{- Low Concentration}

Penggunaan surfactant-polymer flooding, konsentrasi surfaktan yang tinggi memang sangat efektif pada lapisan sandstone. Namun, dibutuhkan tambahan alkali untuk menghasilkan ekstra IFT (interfacial tension). Penggunaan konsentrasi surfaktan yang besar juga akan menimbulkan proses penyerapan (adsorpsi) yang besar. Penggunaan super-surfactant dinilai cukup ekonomis; yaitu dengan konsentrasi yang rendah dapat dihasilkan IFT yang sangat rendah mencapai $10^{-2} \mathrm{mN} / \mathrm{m}$, berdasarkan hasil uji screening laboratorium ((Abrams, A., 1988; Ashayer, R., et. al., 2000; Berger, D., et. al., 2002). Untuk penggunaan pada formasi limestone, dianjurkan untuk menambahkan sodium carbonate guna menurunkan adsorpsi batuan, tanpa mempengaruhi perubahan IFT. Penggunaan seri supersurfactant dinilai cukup ekonomis karena hanya membutuhkan konsentrasi yang rendah 1000 - 3000 ppm. 
Konsentrasi ini sudah memberikan harga IFT yang cukup rendah tanpa penggunaan alkali yang berlebihan, yang cenderung akan menyebabkan proses korosi dan penyumbatan pori-pori batuan (plugging) (Ashayer, R., et. al., 2000; Berger, D., et. al., 2002; Kristanto, D., et. al., 2008; Kristanto, D., 2012).

- $\quad$ Salt Tolerance (Kadar Garam Formasi)

Seri SS ini sangat toleran terhadap kandungan garam air formasi. Studi sebelumnya yang dilakukan oleh Berger et. al menggunakan tipe surfaktan ini dengan $\sim 110.000$ ppm total disolved solids (TDS) dan $\sim 2500$ ppm divalen cations menunjukkan penurunan IFT yang baik, walaupun pada konsentrasi surfaktan $0,05 \%$. Air yang digunakan untuk mencampur pada larutan surfaktan tidak perlu diberi perlakuan dan dilunakkan, dan hal tersebut sangat berpengaruh terhadap pengurangan biaya (Wang Z, et. al., 2001; Goddard, et. al., 2004)

- $\quad$ Emulsi, Korosi dan Scale Reduction.

Masalah pada formasi seperti emulsi, scale dan korosi dapat dihindari karena pada treatment hanya dibutuhkan konsentrasi yang rendah dan tanpa diperlukan alkali untuk menghasilkan tambahan ultra interfacial tension (Wang Z, et. al., 2001; Berger, D., et. al., 2002; Kristanto, D., et. al., 2008).

\subsection{Tahapan Percobaan Coreflooding Test}

Percobaan coreflooding dilakukan menggunakan injeksi surfactant-polymer setelah selesai dilakukan tahapan waterflooding (secondary recovery), seperti ditunjukan pada Gambar 2.

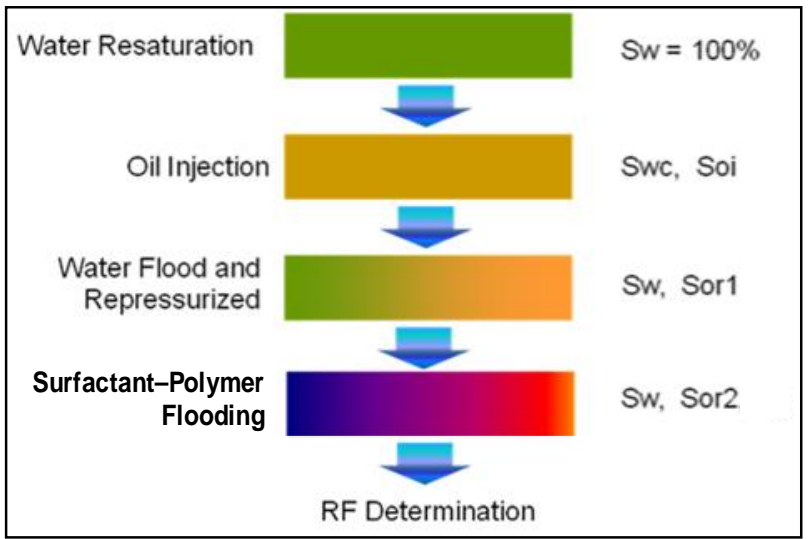

Gambar 2. Mekanisme coreflooding test di laboratorium (After Lemigas, 2012)

Secara rinci, kronologi pendesakan surfactant-polymer adalah sebagai berikut :

- Tahap pertama: core di-resaturasi dengan air formasi $\left(S_{w}=100 \%\right)$

- Dilakukan penginjeksian minyak ke dalam core sampai air tidak keluar lagi dari core (didapat parameter initial oil saturation - $S_{o i}$ dan connate water saturation - $S_{w c}$ )

- Kemudian dilakukan proses penginjeksian air ke dalam core dan dihitung produksi minyak yang didapatkan (tahap waterflooding).
- Proses injeksi air dihentikan setelah minyak tidak keluar lagi dari core (didapat parameter residual oil saturation - $S_{\text {or }}$ dan water saturation - $S_{w}$ ).

- Selanjutnya dilakukan injeksi surfaktan dan polimer sesuai dengan skenario yang dibuat, kemudian dihitung pertambahan produksi minyak yang dihasilkan.

\section{Hasil dan Analisa}

Kajian coreflooding test di laboratorium injeksi surfactantpolymer ini meliputi pengukuran tegangan antarmuka larutan surfaktan pada berbagai konsentrasi dan tipe minyak lapangan; pengukuran reologi polimer; pengukuran sifat-sifat fisik batuan reservoir; dan uji coreflooding.

\subsection{Pengukuran Interfacial Tension}

Surfaktan SS-B8020 dilarutkan dalam air formasi sumur L5A-217 Blok Q-22 dengan beberapa variasi konsentrasi. Selain itu juga dilakukan uji ketahanan suhu dan diperoleh hasil bahwa surfaktan tersebut tidak rusak pada suhu reservoir $\left(104,4{ }^{0} \mathrm{C}\right)$. Hasil pengukuran interfacial tension disajikan pada Gambar 3 dan Tabel 1.

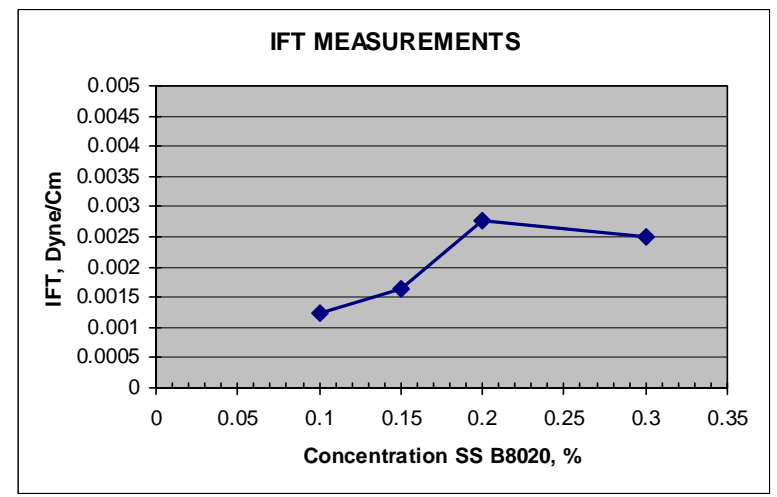

Gambar 3. Grafik hasil pengukuran interfacial tension

Tabel 1. Hasil pengukuran interfacial tension (IFT)

\begin{tabular}{|c|c|c|c|c|}
\hline Surfaktan & $\begin{array}{c}\text { Konsentrasi } \\
(\%)\end{array}$ & $\begin{array}{c}\text { Diluting } \\
\text { Water } \\
\text { Block/Well }\end{array}$ & $\begin{array}{l}\text { Sampel } \\
\text { Minyak }\end{array}$ & $\begin{array}{c}\text { IFT, } \\
\text { dyne/cm }\end{array}$ \\
\hline SS-B8020 & 0,10 & $\begin{array}{l}\mathrm{Q}-22 / \mathrm{L} \\
5 \mathrm{~A}-217\end{array}$ & $\begin{array}{l}\text { Tank- } \\
02 \text { SP } \\
\text { VII }\end{array}$ & $\begin{array}{l}0,001381 \\
0,001230 \\
0,001130\end{array}$ \\
\hline SS-B8020 & 0,15 & $\begin{array}{r}\text { Q-22/L } \\
5 \mathrm{~A}-217\end{array}$ & $\begin{array}{c}\text { Tank- } \\
02 \text { SP } \\
\text { VII } \\
\end{array}$ & $\begin{array}{l}0,001621 \\
0,001670 \\
0,001640 \\
\end{array}$ \\
\hline SS-B8020 & 0,20 & $\begin{array}{l}\mathrm{Q}-22 / \mathrm{L} \\
5 \mathrm{~A}-217\end{array}$ & $\begin{array}{c}\text { Tank- } \\
02 \text { SP } \\
\text { VII } \\
\end{array}$ & $\begin{array}{l}0,002852 \\
0,002761 \\
0,002815 \\
\end{array}$ \\
\hline SS-B8020 & 0,30 & $\begin{array}{l}\mathrm{Q}-22 / \mathrm{L} \\
5 \mathrm{~A}-217\end{array}$ & $\begin{array}{c}\text { Tank- } \\
02 \text { SP } \\
\text { VII }\end{array}$ & $\begin{array}{l}0,002628 \\
0,002578 \\
0,002308 \\
\end{array}$ \\
\hline
\end{tabular}

\subsection{Hasil Analisa Reologi Polimer}

Polimer HYBOMAX 4785 dirancang untuk suhu di atas $100{ }^{\circ} \mathrm{C}$. Selain dilakukan pengamatan reologi juga dilakukan uji ketahanan suhu, di mana polimer diukur 
viskositasnya sebelum dan sesudah dipanaskan sampai $220^{\circ} \mathrm{F}$. Tabel 2 menunjukkan hasil pengukuran viskositas polimer pada suhu $25,70,90$ dan $104^{\circ} \mathrm{C}$. Hasil pengukuran viskositas untuk berbagai konsentrasi (ppm) ditunjukkan pada Gambar 4 sampai dengan Gambar 6.

Tabel 2. Reologi polimer HYBOMAX 4785

\begin{tabular}{ccccccc}
\hline RPM & $\begin{array}{c}\text { Shear } \\
\text { Rate }\end{array}$ & $\mathbf{2 5}{ }^{\circ} \mathbf{C}$ & $\mathbf{7 0}{ }^{\circ} \mathbf{C}$ & $\mathbf{9 0}{ }^{\circ} \mathbf{C}$ & $\mathbf{1 0 4}{ }^{\circ} \mathbf{C}$ & $\mathbf{p p m}$ \\
\hline 6 & 7,92 & 36,5 & 20,7 & 18,5 & 15,78 & \\
12 & 15,8 & 26,5 & 14,3 & 12,4 & 9,09 & \\
30 & 39,6 & 17,9 & 9,4 & 8,65 & 7,06 & 1000 \\
60 & 79,2 & 14,2 & 7,15 & 6,02 & 4,85 & \\
100 & 132 & 11,3 & 6 & 4,91 & 4,10 & \\
120 & 158 & 10,3 & 5,56 & 4,18 & 3,58 & \\
6 & 7,92 & 39,7 & 28,7 & 20,5 & 14,05 & \\
12 & 15,8 & 29,4 & 18,8 & 14,6 & 11,24 & \\
30 & 39,6 & 21,2 & 11,7 & 10,3 & 8,69 & 1100 \\
60 & 79,2 & 16 & 9 & 6,37 & 4,74 & \\
100 & 132 & 13,5 & 7,22 & 5,6 & 4,13 & \\
120 & 158 & 12,2 & 6,49 & 4,44 & 2,60 & \\
\hline 6 & 7,92 & 41 & 31 & 22,5 & 15,27 & \\
12 & 15,8 & 31,2 & 21,3 & 16 & 13,03 & \\
30 & 39,6 & 22 & 13,8 & 11,65 & 10,54 & 1200 \\
60 & 79,2 & 17 & 10,3 & 7,97 & 6,82 & \\
100 & 132 & 14 & 8,45 & 6,56 & 5,62 & \\
120 & 158 & 13 & 7,31 & 5,75 & 5,00 & \\
\hline
\end{tabular}

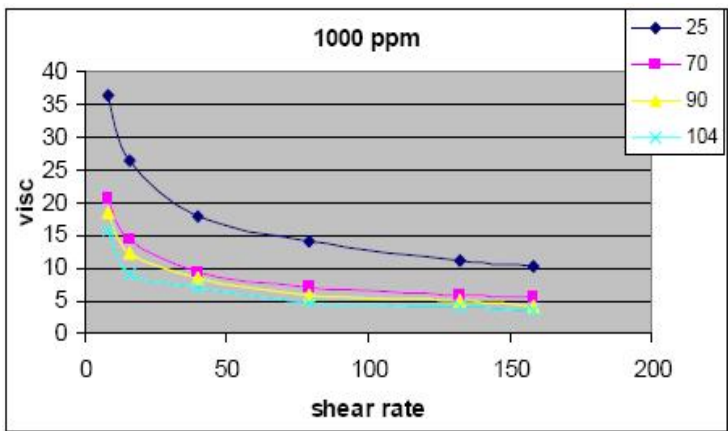

Gambar 4. Viskositas polimer HYBOMAX 4785 konsentrasi 1000 ppm

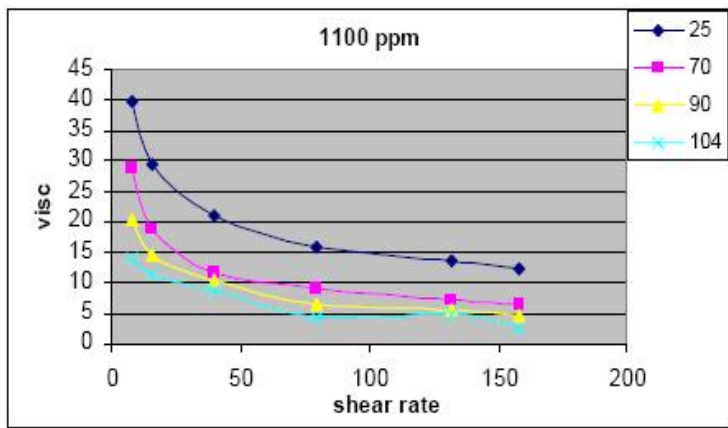

Gambar 5. Viskositas polimer HYBOMAX 4785 konsentrasi $1100 \mathrm{ppm}$

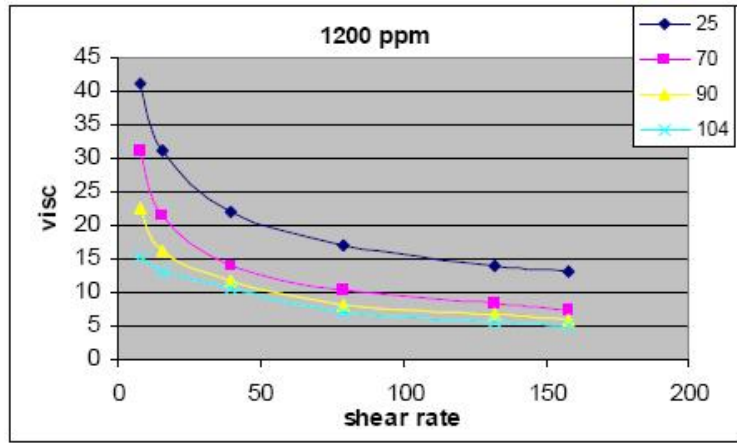

Gambar 6. Viskositas polimer HYBOMAX 4785 konsentrasi 1200 ppm

\subsection{Hasil Analisa Sampel Minyak}

Sampel minyak telah dilakukan pengukuran viskositas pada berbagai suhu, juga pada suhu reservoirnya $\left(104,4{ }^{0} \mathrm{C}\right)$. Hasil pengukuran tersebut ditunjukan pada Tabel 3 .

Tabel 3. Hasil pengukuran viskositas minyak

\begin{tabular}{cccccccc}
\hline \multirow{2}{*}{ RPM } & \multirow{2}{*}{$\begin{array}{c}\text { Shear } \\
\text { Rate }\end{array}$} & \multicolumn{2}{c}{$\mathbf{7 0}^{\circ} \mathbf{C}$} & \multicolumn{2}{c}{$\mathbf{9 0}^{\circ} \mathbf{C}$} & \multicolumn{2}{c}{$\mathbf{1 0 4}^{\circ} \mathbf{C}$} \\
\hline $\mathbf{c p})$ & $\begin{array}{c}\text { Torque } \\
(\%)\end{array}$ & $\begin{array}{c}\text { Visc. } \\
(\mathbf{c p})\end{array}$ & $\begin{array}{c}\text { Torque } \\
(\%)\end{array}$ & $\begin{array}{c}\text { Visc. } \\
(\mathbf{c p})\end{array}$ & $\begin{array}{c}\text { Torque } \\
(\%)\end{array}$ \\
\hline 6 & 7,92 & 9,3 & 1,9 & 2,8 & 0,5 & 3,75 & 0,8 \\
12 & 15,8 & 7,4 & 2,8 & 3,2 & 1,2 & 2,4 & 1,8 \\
30 & 39,6 & 6,6 & 6,6 & 3,7 & 3,7 & 3,15 & 3,2 \\
60 & 79,2 & 6,1 & 12,1 & 3,65 & 7,4 & 3,08 & 6,1 \\
100 & 132 & 6,09 & 20,4 & 3,82 & 12,7 & 3,30 & 11 \\
120 & 158 & 6,09 & 24,3 & 3,84 & 15,3 & 3,24 & 13 \\
\hline
\end{tabular}

\subsection{Pengukuran Sifat-Sifat Fisik Core Plug}

Sampel core dibor untuk menghasilkan core plug dengan ukuran panjang sekitar 3 inchi dan diameter 1,5 inchi. Dua core plug telah dihasilkan dan data lengkapnya ditunjukkan pada Tabel 4.

Tabel 4. Sifat-sifat petrofisik core

\begin{tabular}{cccccccc}
\hline No. & $\begin{array}{c}\text { Panjang } \\
(\mathbf{c m})\end{array}$ & $\begin{array}{c}\text { Dia } \\
\text { meter } \\
(\mathbf{c m})\end{array}$ & $\begin{array}{c}\text { Volume } \\
\text { Bulk } \\
(\mathbf{c c})\end{array}$ & $\begin{array}{c}\text { Volume } \\
\text { Butir } \\
(\mathbf{c c})\end{array}$ & $\begin{array}{c}\text { Volume } \\
\text { Pori }(\mathbf{c c})\end{array}$ & $\begin{array}{c}\text { Porositas } \\
(\boldsymbol{\%})\end{array}$ & $\begin{array}{c}\text { Perm. } \\
\text { Gas } \\
(\mathbf{m D})\end{array}$ \\
\hline 1 & 8,052 & 3,834 & 92,960 & 72,196 & 20,764 & 22,34 & 2405,00 \\
2 & 7,385 & 3,828 & 85,027 & 63,6 & 21,427 & 25,20 & 1653,17 \\
\hline
\end{tabular}

\subsection{Hasil Coreflooding Test-1}

Skenario injeksi kimia pada penelitian ini telah dirancang dengan konsentrasi masing-masing surfaktan 1000 ppm sebanyak 0,3 volume pori diikuti dengan polimer $1200 \mathrm{ppm}$ sebanyak 0,3 volume pori. Proses injeksi diulang dengan konsentrasi surfaktan 1500 ppm sebanyak 0,3 volume pori dan polimer $1200 \mathrm{ppm}$ sebanyak 0,3 volume pori. Hasil dari pengulangan injeksi pada core No. 1 ini memberikan hasil yang kurang baik karena konsentrasi surfaktan yang digunakan masih terlalu rendah sehingga belum optimal pengaruhnya terhadap perubahan sifat-sifat fisik batuan dan fluida reservoir serta perolehan minyaknya (recovery factor). Kronologi pelaksanaan hasil injeksi coreflooding test-1 ditunjukkan pada Gambar 7, sedangkan hasil lengkap percobaan ditunjukkan pada Tabel 5 dan Tabel 6 . 


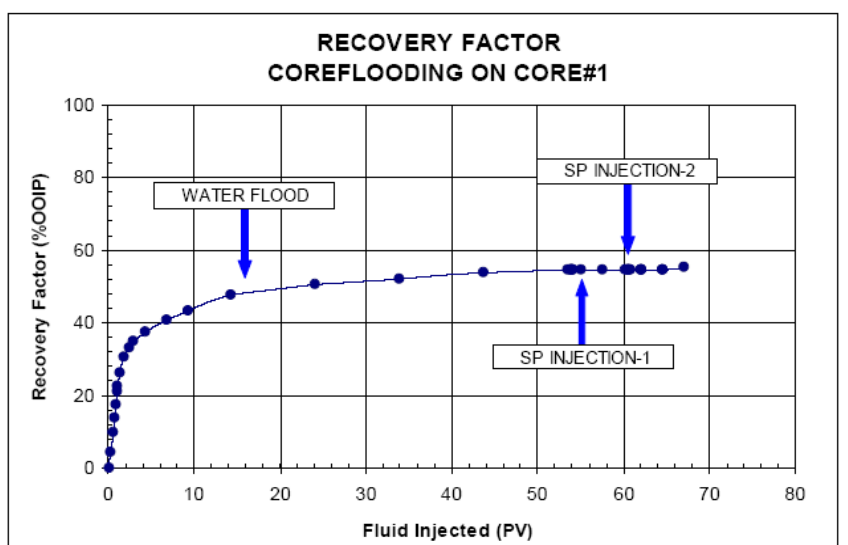

Gambar 7. Hasil coreflooding test-1

Tabel 5. Perubahan sifat batuan pada coreflooding-1

\begin{tabular}{cccccc}
\hline $\begin{array}{c}\text { Core } \\
\text { No. }\end{array}$ & $\begin{array}{c}\boldsymbol{K}_{a} \\
(\mathbf{m D})\end{array}$ & $\begin{array}{c}\boldsymbol{K}_{w} \\
(\mathbf{m D})\end{array}$ & $\begin{array}{c}\boldsymbol{K}_{\boldsymbol{o}} @ \boldsymbol{S}_{w c} \\
(\mathbf{m D})\end{array}$ & $\begin{array}{c}\boldsymbol{K}_{w} @ \boldsymbol{S}_{\text {or1 }} \\
(\mathbf{m D})\end{array}$ & $\begin{array}{c}\boldsymbol{K}_{w} @ \boldsymbol{S}_{\text {or2 }} \\
(\mathbf{m D})\end{array}$ \\
\hline 1 & 2405,00 & 614,35 & 325,68 & 62,64 & 30,29 \\
\hline
\end{tabular}

Tabel 6. Hasil coreflooding test-1

\begin{tabular}{|c|c|c|c|c|c|c|c|}
\hline \multirow[t]{2}{*}{$\begin{array}{c}\text { Core } \\
\text { No. }\end{array}$} & \multirow[t]{2}{*}{$\underset{\text { (cc) }}{\text { OOIP }}$} & \multicolumn{2}{|c|}{$\begin{array}{c}\mathbf{R F} \\
\text { Waterflood }\end{array}$} & \multicolumn{2}{|c|}{$\begin{array}{c}\mathbf{R F} \\
\text { Chemical } \\
\text { Flood-1 }\end{array}$} & \multicolumn{2}{|c|}{$\begin{array}{c}\text { RF } \\
\text { Chemical } \\
\text { Flood-2 }\end{array}$} \\
\hline & & (cc) & $(\%)$ & (cc) & $(\%)$ & (cc) & $(\%)$ \\
\hline 1 & 10,85 & 5,90 & 54,39 & 0,00 & 0,00 & 0,09 & 0,80 \\
\hline
\end{tabular}

\subsection{Hasil Coreflooding Test-2}

Untuk memperbaiki hasil injeksi telah dilakukan modifikasi, di mana injeksi surfaktan dilakukan dengan konsentrasi 3000 ppm sebanyak 0,3 volume pori dan diikuti dengan injeksi polimer dengan konsentrasi 1000 ppm sebanyak 0,2 volume pori. Hasil dari injeksi ini telah menaikkan recovery factor sebesar 12,89\% OOIP. Kronologi hasil injeksi dan water cut dapat dilihat pada Gambar 8 dan Gambar 9, sedangkan hasil lengkap uji coreflooding test-2 ditunjukkan pada Tabel 7 dan Tabel 8 .

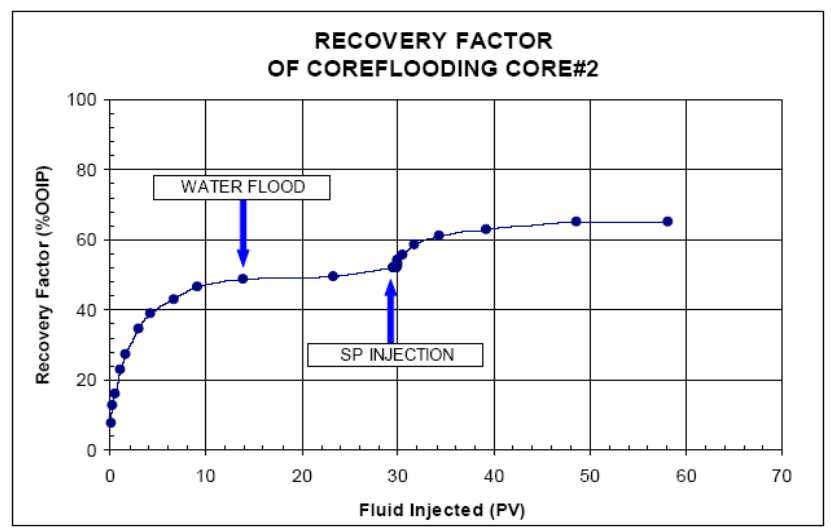

Gambar 8. Hasil coreflooding test-2

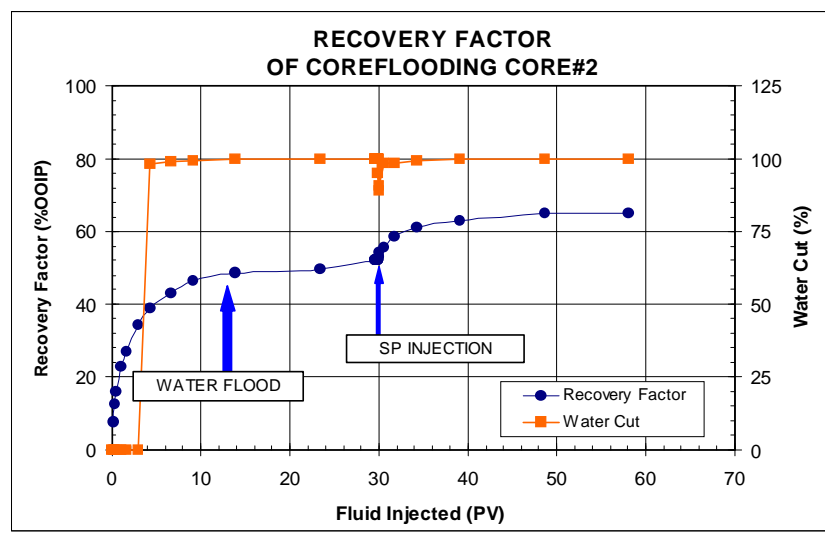

Gambar 9. Kadar air coreflooding test-2

Tabel 7. Perubahan sifat batuan pada coreflooding-2

\begin{tabular}{cccccc}
\hline $\begin{array}{c}\text { Core } \\
\text { No. }\end{array}$ & $\begin{array}{c}\boldsymbol{K}_{a} \\
(\mathbf{m D})\end{array}$ & $\begin{array}{c}\boldsymbol{K}_{w} \\
(\mathbf{m D})\end{array}$ & $\begin{array}{c}\boldsymbol{K}_{o} @ \boldsymbol{S}_{w c} \\
(\mathbf{m D})\end{array}$ & $\begin{array}{c}\boldsymbol{K}_{w} @ \boldsymbol{S}_{\text {orl }} \\
(\mathbf{m D})\end{array}$ & $\begin{array}{c}\boldsymbol{K}_{w} @ \boldsymbol{S}_{\text {or2 }} \\
(\mathbf{m D})\end{array}$ \\
\hline 2 & 1653,17 & 276,77 & 198,08 & 61,51 & 27,68 \\
\hline
\end{tabular}

Tabel 8. Hasil coreflooding test-2

\begin{tabular}{c|c|c|c|c|c}
\hline \multirow{2}{*}{$\begin{array}{c}\text { Core } \\
\text { No. }\end{array}$} & \multirow{2}{*}{ OOIP (cc) } & \multicolumn{2}{|c|}{ RF Waterflood } & \multicolumn{2}{c}{$\begin{array}{c}\text { RF Chemical } \\
\text { Flood }\end{array}$} \\
\cline { 3 - 6 } & & $(\mathbf{c c})$ & $\mathbf{( \% )}$ & $(\mathbf{c c})$ & $(\%)$ \\
\hline 2 & 11,63 & 6,44 & 56,38 & 1,50 & 12,89 \\
\hline
\end{tabular}

\subsection{Kondisi Surfaktan Setelah Coreflooding Test}

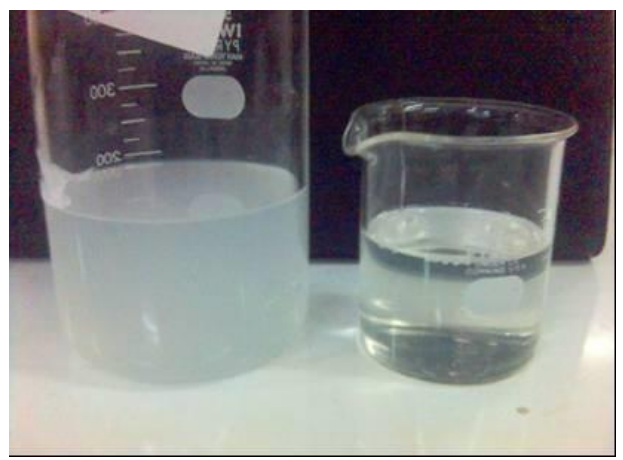

(a)

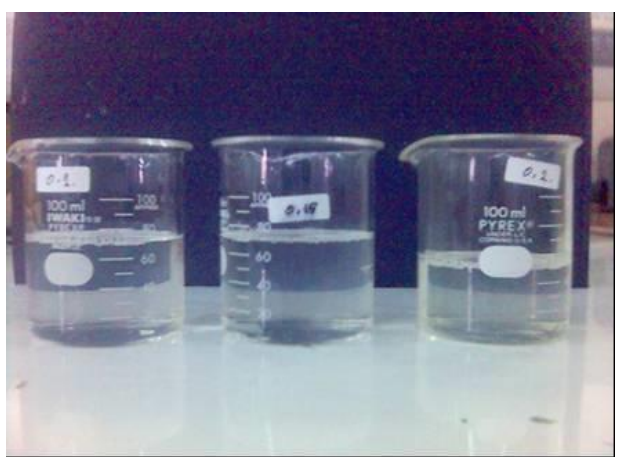

(b)

Gambar 10 (a) Surfaktan SS B8020 konsentrasi 0,3\% dibandingkan dengan jenis lain (b) Surfaktan SS B8020 konsentrasi $0,1-0,2 \%$ setelah coreflooding test-2 
Cairan surfaktan SS B8020 setelah digunakan untuk coreflooding test pada berbagai konsentrasi $(0,1-0,3 \%)$ ditampung kembali pada gelas beaker kemudian didiamkan selama 7 (tujuh) hari pada kondisi temperatur reservoir untuk melihat perubahan kondisi fisik cairan surfaktan tersebut. Dari hasil pengamatan terlihat bahwa kondisi cairan surfaktan SS B8020 tidak mengalami perubahan warna (tetap jernih) dan relatif sama seperti sebelum diinjeksikan ke dalam core plug dan tidak terjadi penggumpalan partikel (particle suspension), seperti ditunjukkan pada Gambar 10 (a) dan Gambar 10 (b). Hal ini menunjukkan bahwa surfaktan SS B8020 tidak menyebabkan terjadinya penyumbatan (plugging) pada pori-pori core plug (batuan reservoir).

\section{Kesimpulan}

a. Hasil pengukuran properti surfaktan dan polimer menunjukkan hasil yang baik untuk digunakan sebagai material injeksi untuk meningkatkan perolehan minyak.

b. Injeksi surfactant - polymer dengan konsentrasi 3000 ppm dan 1000 ppm masing-masing sebanyak 0,3 volume pori dan 0,2 volume pori menghasilkan peningkatan perolehan minyak sebanyak $12,89 \%$.

c. Penggunaan surfaktan SS B8020 sebagai fluida injeksi tidak menyebabkan terjadinya penyumbatan (plugging) pada pori-pori batuan reservoir.

\section{Rekomendasi}

a. Perlu dilakukan variasi konsentrasi surfaktan dan polimer dalam kajian laboratorium dan simulasi reservoir agar didapatkan komposisi yang lebih optimal dalam upaya untuk meningkatkan perolehan minyaknya.

b. Hasil kajian ini dapat digunakan sebagai referensi untuk diterapkan di lapangan baik melalui mekanisme huff-and-puff (soaking) maupun secara pilot project dan full-scale.

\section{Ucapan Terimakasih}

Penulis mengucapkan terima kasih dan penghargaan kepada PT. Petroleum Nusantara Energy yang telah berkenan membantu mendanai penelitian ini, dan juga Laboratorium EOR PPPTMGB "LEMIGAS" yang telah membantu dan memfasilitasi pelaksanaan pengujian di laboratorium sehingga penelitian ini dapat berjalan dengan baik dan lancar.

\section{Daftar Pustaka}

Anderson, A. G., (2006), Simulation of chemical flood EOR processes including the effects of reservoir wettability, a Thesis for Degree of Master of Science in Engineering, The University of Texas, Austin.
Ayirala, C. S., (2002), Surfactant induced relative permeability modifications for oil recovery enhancement, Thesis for Degree of Master of Science in Department of Petroleum Engineering, Kharagpur, India.

Ashayer, R., Grattoni, C. A., and Luckham, P. F., (2000), Wettability Changes During Surfactant Flooding, $6^{\text {th }}$ International Symposium on Evaluation of Reservoir Wettability and its Effect on Oil Recovery, Socoro, New Mexico, Sept. 27-28.

Abrams, A., (1988), The influence of viscosity, interfacial tension, and flow velocity on residual oil saturation left by waterflood, SPE Reprint Series No. 24 Vol. 1, Tulsa, Oklahoma.

Buckley, S. J., (1997), Evaluation of Reservoir Wettability and Its Effect on Oil Recovery, prepared for U.S Department of Energy, Tulsa, Oklahoma, Reporting Period: July 1, 1996-June 30, 1997.

Berger, D. and Lee, C. H., (2002), Ultra-low Concentration Surfactants for Sandstone Floods, SPE 75186, SPE/DOE Improved Symposium, Tulsa, Oklahoma, April 13-17.

Goddard, William, A, Yongchun, T., (2004), Lower cost methods for improved oil recovery (IOR) via surfactant flooding, Final Report, California Institute of Technology.

Kristanto, D, Fibarata, A. A, and Windiarto, B., (2006), Kajian penggunaan surfactant untuk meningkatkan perolehan minyak, Lab Report, UPN "Veteran" Yogyakarta.

Kristanto, D., Widiyarso, A., and Wibowo., (2008), Evaluation of the Utilization of Low Concentration Surfactant Using Soak Injection Treatment Method, IATMI 08-049, Society of Indonesian Petroleum Engineers (IATMI) Conference, November 12-14, Jakarta.

Kristanto, D., (2012), Laboratory Study of Improvement Oil Recovery Using Soaking Surfactant Flooding Method, C10-1, National Seminar of Chemical Engineering - 2012, Chemical Engineering Department of Universitas Pembangunan Nasional "Veteran” Yogyakarta, March 6, Yogyakarta.

Nugroho, S. B., Ardianto, R. N., and Kristanto, D., (2010), Integrating Production Analysis as a Plan of Pattern Selection for Chemical Flood Pilot Project in Limau Block, Pertamina EP, SPE 126578-PP, Society of Petroleum Engineers - North Africa Technical Conference and Exhibition (SPE-NATCE), Cairo, Egypt, 14-17 February.

Shen, P, Zhu, B, Li, X, and Wu, Y. S., (2006), The Influence of Interfacial Tension on Water/Oil TwoPhase Relative Permeability, SPE 95405, SPE/DOE Symposium on IOR, Tulsa, Oklahoma, April, 22-26.

Wang Z, Zhao F, Lushan W, and Jiyong L., (2001), Surfactant Oil Displacement System in High Salinity Formations: Research and Application SPE 70047, Society of Petroleum Engineers Permian Oil and Gas Recovery Conference, Mildland-Texas, May 15-16. 